\title{
Improving Students Listening Skill through Interactive Multimedia in Indonesia
}

\author{
Arono \\ Department of Art and Language Education, University of Bengkulu, Indonesia
}

\begin{abstract}
Leraning method inovation will influence learning media used and it is hoped to improve learning qualities. One of them is improving students' critical listening ability. This research was done to know the students activities in learning critical listening by using interactive multimedia and to measure the effetiveness of that multimedia in improving students' critical listening ability. The data was taken through test, observation, and interview. The result of the research were (1) the students created active, creative, and effective learning process independenly in measuring and developing each step of listening learning model. (2) Interactive multimedia was effective learning media to improve students' critical listening skill. It could be

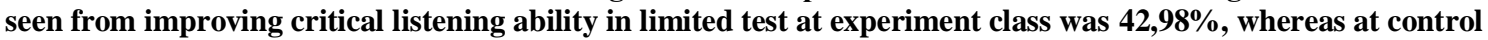
class the rise was only $7,36 \%$. For extensive test, the improving of critical listening ability at experiment class was $33,88 \%$, while control class was only up at $2,62 \%$. (3) Critical listening strategy performance in PMAI Model could improve students' critical listening ability so that this model is better to be applied as an implimentation of reference in listening learning model. (4) Learning media with interactive multimedia can improve students' critical listening skill than audio learning media because listening is not only aural aspet but also visual aspect integrated with multimedia.
\end{abstract}

Index Terms - effectiveness, interactive multimedia, critical listening skill

\section{INTRODUCTION}

Learning listening has been developed and advanced especially in media and in learning materials used in the cities. There are many choices of listening materials such as CD, DVD, or video applied in the classroom. However, there are many evidences that listening is lack attention of teachers (Field, 2009, p.1). When they applied many learning competencies in the classroom, listening skill was always accelerated or reduced. Learning course methodology was discussed and analyzed slightly, and there was a tendency from the teachers that listening was ordinary activity in life. The other factor was a lack of teachers' commitment to apply an appropriate approch in listening like using integrative skill which affected listening as an indicator to teach it in haste. Reading and Listening skills were as primary in learning language skill.

The relevance of critical listening with learning listening is to prepare the students in order to be the best solver, make the better decision, and long life education. It is important for the students to be independent thinker since there are many jobs needed skillful workers which have critical listening ability. All this time, critical listening ability has not absorbed yet to the students' soul so it could not be function maximally in the society. Meanwhile, high level cognitive learning could help the students to be independent students which could develop reflective and logical thinking to decide some problems (Ennis in Costa, 1985). Today, many students are less to apply knowledge gotten from shool to face their daily life problems since they cannot give some prove about some concepts and its connecction to their problems.

Listening skill is a process in language skill that needs practice by using audio/technology such as a research done by Embi and Latiff (2004) in using E-learning as a tool for learning ESL. After practicing, the students agreed that comprehension of listening ablity had been incerased significantly. Morover, in Hong Kong, Chapple and Curtis (2000), adopted strip film as teaching material for ESL which had 31 EFL students and got answer 67,8\% students said that they had possitive impact in listening skill within 13 weeks learning. Therefore, teaching of intensive multimedia could raise students' EFL listening skill comprehension. It could be seen that there were many less developed students in listening English skill applied internet, computer, or multimedia could help students' EFL/ESL (Chapelle, 2000). Some listening activities have been apllied in listening practice but most of them used listening material from cassette, television, and radio whereas using technology was seldom in learning listening. These were happened because using internet was still lack for listening media and there was not software for learning listening model.

However, there was an internet that could be accessed by the students as a learning media. That utilization combination media could create the latest listening learning media product. According to Meskill (1996) multimedia could improve listening skill focused on: (a) visual and text roles as a tool to organize language in aural teks; (b) video motivation aspect as a profit for language teachning; (c) a fact that those media combinations could reach language target so that they could give important input to language acquisition process (d) comfortamble environment to describe chart and discourse strategy for the students. 
Listening as a basic of language skill was as a fundamental for interactive multimedia development in improving students' critical listening skill. Listening skill refered to some theories such as from Morris (1969, p.701-702), Grene et. al. (1969), Logan (1972, p.39), Tarigan (1986, p.27-29), Meskill (1996), Richard \& Rubin (in Van Duzer, 1997), Sutari (1997, p.16-19), Ginther (2002) and Ockey (2007). Morris explained listening proess such as hearing, attention, perception, evaluation, and response or reaction. Gren dan Loban described listening process into hearing, understanding, evaluating, and responding. Besides, Logan gave some steps for listening process like comprehending, interpenting, and evaluating. Tarigan and Sutari also suggested that the term of hearing and listening were related element with different meanings in language teaching. Hearing was an activity of process to accept words or sentences accidentally whereas listening was listening activity done by fully attention, comprehension, appreciation, interpretation to get information, to get message, and to understand communicative meaning that have been expressed by the speaker. Moreover, Richard \& Rubin said that listening did not oly comprehend the utterances of speakers, but also understood visual aspect in activities of listening comprehension. Based on those explanations, listening was a process included activity of listening sound of language and visual aspect, identify, interprete, value, and do reaction for the content of meaning. This term was used as the fundamental in developmet of active integrative listening learning model.

Some theories of active integrative listening learning refered to Vandergrift's theory (1999), Flowerdew \& Miller (2005, p.18), Harris (2007), Thompson et. al. (2009, p.269), and Thompson (2010, p.268-271). Vandergrift and Harris explained that active integrative listening learning was focused on metacognitive knowledge started from planning, directed attention, selective interest, monitor, and evaluation. Flowerder dan Miller paid attention much to integrative listening learning like pre-listening, while-listening, and post listening. Thompson also desribed active integrative listening learning which could be done into some steps like prepare for listening activity, apply listening model, value listening effectiveness, and implement new goal in listening activity.

Based on those theories, the writer used them as a fundamental in developing active integrative listening learning model in interative multimedia learning. In this research, the writer formulated integrative active listening learning model was based on students center focused on pre- listening, while listening, and post listening activities. Those steps were unity and dynamic in learning integrated with attitude, knowledge, and behavior to achieve listening goal. In pre listening stage, there were some preparations like noticing and reflecting key words; in while listening, the students did listening process by clarifying meaning and performance effectiveness; and in post listening stage, students reflected listening purpose by determining wether listening result accepted or not acepted. It can be seen from a diagram of integrative active listening model as following.

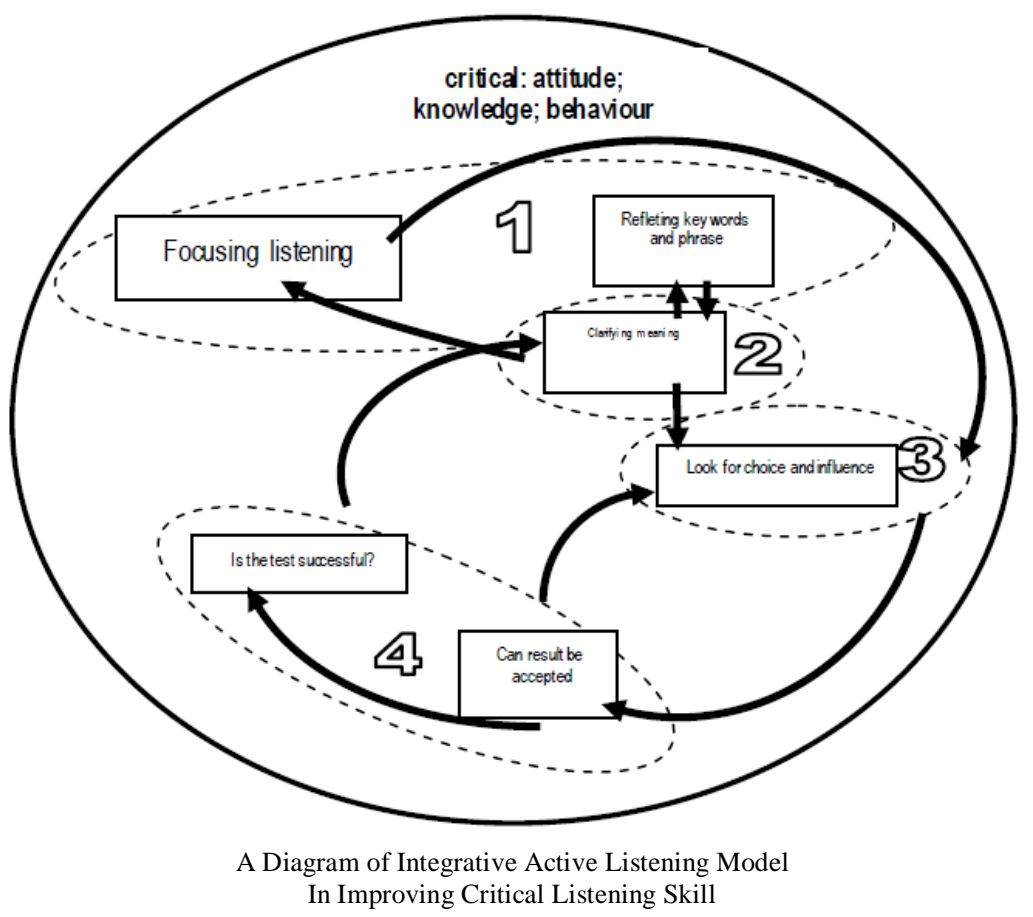

Interagtive multimedia was an alternative tool for critical listening learning that could be applied by the lecturer using educational technology in learning which had text, sound, picture, animation, video, and interaction aspects. By giving interactive additional aspect, the users or the students were active to choose one of them and search information in following those stages based on their need. This interactive multimedia formulation was suggested by Prabath and Andleight (1996), Mayer (2001, p.270-271), and Blanco (2007, p.37-44). Prabath and Andleight and Blanco said that multimedia consisted of five basic types: text, animation, video, picture, and sound, whereas Mayer emphasized in using multimedia in order to be better in appliying, coherence, modality reduncy, and individual differences. Applying 
of this integrative multimedia could be done by using computer presented through projector in learning. The students could observe, study, and ask the lecturer about the material presented in projector. Using interagtive multimedia technology was integrated in goal and in the content of learning which were written in program in order to increase the quality of teaching ativity.

Learning media was said good if that media could convey the message and could be understood by the students. Before that media was used in the classroom, it was needed to do assessment. It could be done by paying attention to criteria of good media. To evaluate learning media refered to Ivers dan Baron's theories (2002) and Thompson (in Flowerdew \& Miller, 2005, p.180). Ivers and Baron suggested that good media was outline content, flocart view, storyboard, technique, design, and presentation. Then, according to Thompson (in Flowerdew \& Miller) said that media criteria was as evaluation activities in documentation, listening tool, and related to listening activities. Both theories in evaluating learning media completed each other, and Thompson's theory technically had been reported in Ivers and Barons theories.

Critical listening was a part of activities in intensive listening. Based on listening goal, intensive listening was listening activities which were more control and more emphasized in language component perception. It was the same with Tarigan (1990, p.40) and Brown (2004, p.120) reported that critical listening skill was a skill involved interpretative, introspective, responsive, and productive listening, and evaluative events. Further, Tarigan asserted that critical listening was listening activities to look for not only error and mistake but also good utterances from the speakers with strong result accepted by the listener. Therefore, critical listening learning development refered to some indicators based on critical thingking and critical listening theories presented by Anderson (1972, p.70) and Costa (1985). The writer formulated those theories since both critical listening concept and critical thinking basically involved mental aspect.

\section{Methodology}

This research was quasi experiment (Fraenkel \& Wallen, 2007, p.271). To see the effectiveness of interactive multimedia in integrative active listening learning as determinant of critical listening improvement, the researcher used limited and extended tests in experimental and control classes. There were 89 students in experimental class by applying interactive multimedia integrated in learning of interactive active listening, whereas 126 students were in control class by implementing audio learning media used handbook of interactive active listening learning model. Each group was divided into high, everage, and low levels for extended test, while students' input in experimental and control classes for limited test was more varied. Determining of group distribution was based on placement test. Experiment was done in limited and extended tests both in experimental and control classes (The Matching-Only Pratest-Posttest Control Group Design). Effectiveness was measured by comparing pre-test and post-test. The tests were multiple choice, listening and writing, listening and speaking through interactive multimedia program for experimental class, whereas control class used audio program with handbook. If post-test was higher than pre-test, interactive multimedia was called effective.

\section{RESUlT AND ANALYSIS}

Multimedia was combination between sight and auditory. Those combination could raise a phenomenon or object effectively (Yusup, 1990). It was related to relationship between kind of media with memory of human being to accept and save a message like, audio 10\%, visual 40\%, and audiovisual 50\% (Siswosumarto, 1994). They should be designed in order to achive learning goal as critical listening laerning media.

Learning media was applied interative multimedia. It was called learning media because it was well designed to stimulate thingking, feeling, attention, and will of the students so learning process happened. Besides, learning media was one of dominant aspects after learning method which could improve learning process and achieve high learning result (Sudjana and Rivai, 2007, p.2). Beacause of that, interative multimedia design was made suitable with learning model development.

In interactive multimedia development stage, there were some cases that should be paid attention in pre-product, while-product, and pasca-product. Suyanto (2005, p.388) described that pre-product was activities before multimedia was producted, while-product was a period during multimedia was producted, whereas pasca-product was a period after multimedia was producted.

Pre-product stage was done by learning and analyzing document, by conference of manuscript, and continuing with designing media visualization producted. In this stage, it was also planned product activities such as preparing tools and material production, preparing facilities, preparing location, arranging time schedule, planning cost, and processing permission letter. Producer should know not only only hardware multimedia like (input unit, central precessing unit (CPU), storage/memory, and output unit) but also software multimedia (processing system, programs controlled multimedia computer, macromedia flash).

While-product was making master program, doing review and revise program, and reproduction integrated with PMAIMI Model. It was also done expert judgement to get information about weaknesses interactive multimedia PMAI Model. Those weaknesses were as the basic to do correction. After that, interactive multimedia were ready to tryout in 
learning PMAIMI Model at limited test. Then, the revisions of PMAIMI Model at limitet test were developed in extended test in order to get effective PMAIMI Model in improving students' critical listening skill. If interactive PMAIMI Model was effective, learning media of interactive multimedia could be socialization in advanced media development to be applied for public. Because of that, in designing interactive multimedia needed systematic and integrated stages so that media product was appropriate with goal of interactive multimedia development.

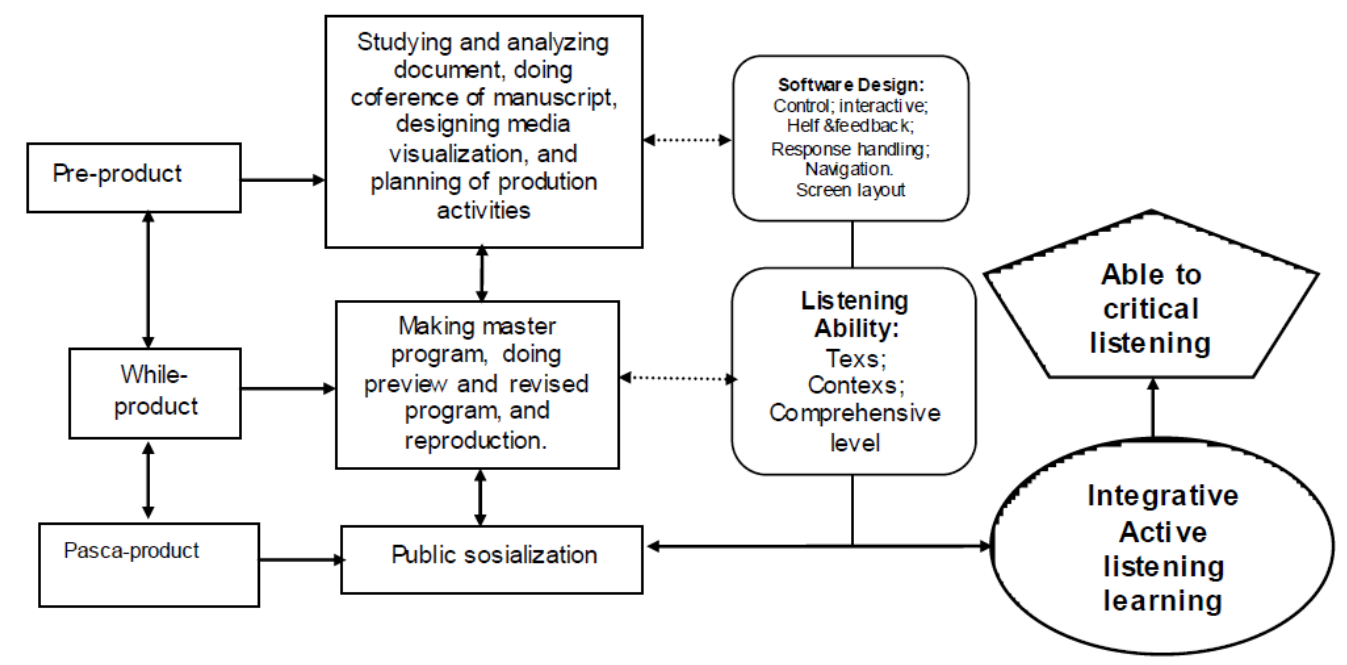

Diagram of Interative Multimedia Development Design

It was modification from Hoven, Plass, and Jones designs (in Jones, 2008). They claimed that multimedia design toward listening skill enhancement would be more effective in improving students' listening ability. It was also based on instructional design, collaborated active integrative listening learning model, and designed software for improving listening comprehension through multimedia. Hoven suggested that software centered design must be in consistent environment used the same strategies in learning activities. He further reported that software should involve knowledge about effective strategy, understanding of aural and visual theorities, and consideration related to applying learning model. This design could make the students learned the material and studied individually so they could understand their critical listening. According to Jones (2008) listening was not only accepted aural but also could make the students process written input or visual information. It made the students more effective in understanding information through multimedia both in cognitive and metacognitive aspects.

Before implementing extetended test in each classroom, the researcher did pre-test toward students' critical listening skill in critical listening skill performance both in spoken-listening and written-listening by having good category in beginning median 125,9 for PMAIMI Model and also good category for PMAMA Model with 128,5. After that, the reseaher did four times treatment. Indicators for spoken-listening were identifying questions, ability to decide different information, ability to determine information objectively and evaluative, and ability to make summary. Meanwhile, indicators for written-listening were ability to consider responses, ability to establish new information, accuracy utterance and sentence element, and capability to do generalization and hipotesis.

\section{A. Performance Students' Critical Listening Skill}

Performance analysis for critical listening comprehensive ability was done by counting median level with formula total answer was divided with total respondents by using interval scale 31. It was said excellent if the level of achievement was 129-160, very good was at 97-128, good was at 65-96, poor was at 33-64, and fail was at 0-32. It would explain below each treatment of students' critical listening skill through PMAIMI Model and PMAIMA Model at extended test.

Performance of PMAIMI Model critical listening at treatment focused on an ability to identify questions for spokenlistening and ability to consider the answer written-listening. After doing learning activities, performance of critical listening ability was at 66,8 median. It was also at 54,9 median in PMAIMA Model. Then, performance PMAIMI Model critical listening at second treatment focused on the ability to decide different information for spoken-listening and ability to determine new information for written-listening. After doing learning activies, performance of critical listening was at 70,1 median. For PMAIMA Model in this treatment, performance of critical listening ability was at 52,6 median. Performance of critical listening PMAIMI Model at third treatment focused on the ability to establish information objectively and evaluative for spoken-listening and utterances accuracy and sentences alement for writtenlistenig. After doing learning activities, performance of critical listening ability was at 71,1 median. PMAIMA Model in the third treatment, performane of written-listening for critical listening ability was at 52,5 median. For performance of PMAIMI Model Critial listening at the fourth treatment focused on the ability to summarize for spoken-listening and ability to generalize and hypotesis for written-listening. After doing learning activities, performance of critical listening ability was at 72,9 median in very good level so that it was improvement at final test by having 76,8 median. The 
average of performance students' critical listening ability in this treatment impled that performance of students' critical listening ability in summary was interpretative and not focused on listening material, however the summary had not been in a good arrangement yet. Otherwise, performance of students' critical listening ability in determining hypotesis was productive, focused on listening material, but hypotesis made lack of good arrangement. However, PMAIMA Model for this fourth treatment, performance of critical listening ability was at 51,4 in poor level and until final test was still at poor catagory but it was improvement at 56.9 .

\section{B. Analysis of Students' Critical Listening Comprehensive Ability}

Before implementing extended test in each classroom, the researcher was done pre-test to know students' critical listening comprehensive ability both in spoken-listening and written-listening with average 125,5 at very good category for PMAIMI Model, and 128,6 also at very good category for PMAMA Model. After having the result of pretest, the researcher did four time treatments.

Analysis of performance in each treatment at extended tryout test was done by counting the average of critical listening skill achievement that was answered total was divided by total respondent with 12 interval scale. The conversion was qulified excellent if the achievement level was at 53-65, very good was at 40-52, good was at 23-39, poor was at $14-26$, and very poor was at $0-13$.

At the first treatment, students' critical listening comprehension ability for spoken-listening dan written-listening both in experiment and control classes at good category (PMAIMI Model=36,8 and PMAIMA Model= 35,3). Second treatment for students' critical listening comprehension ability for spoken-listening and written-listening both in experiment and control classes was at good category (PMAIMI Model=38,5 and PMAIMA Model= 39,9). Third treatment for students' critical listening comprehension ability or spoken-listening and written-listening was different. Experiment class was better than control class to their critical listening comprehension bility. PMAIMI Model experiment class was very good category (43,7), whereas PMAIMA Model was good category (34,3). It was also happened for four treatment. Experiment class was better than control class. PMAIMI Model experiment class was very good (47,3), while PMAIMA Model was good (38,3). It meant that spoken-listening and written-listening PMAIAMI Model for students' critical listening comprehension ability was high acuracy with a little mistake in listening contents comprehension, listening contents detail comprehension, speaking and writing fluency, diction accuracy, sentence accuracy, spelling and grammar, and meaningful of utterances. At post test, students' critical listening comprehension ability improved at excellent category $(136,8)$. It meant that students' critical listening comprehension ability both in spoken-listening and in written-listening were almost no error. However, students' critical listening comprehension ability was good category at PMAIMI Model.

\section{Enhancement of Critical Listening Learning Result}

Besides analysis test, such as pretest-pretest, posttest-postest, gain test between experiment and control groups from category analysis at pre-test and pos-test consilidated analysis result about whether PMAIMI Model was better in improving students' critical listening skill than PMAIMA Model. The following was presented gain analysis amplified with change visualisation at critical listening ability both at its presented establisment and at students' number.

TABLE OF CRITICAL LISTENING ABILITY FREQUENCY DistRIBUTION AT EXPERIMENT AND CONTROL CLASS BOTH IN PRE-TEST AND POST-TEST

\begin{tabular}{|l|l|l|l|l|}
\hline Group & Pretest & Postest & d & $d^{2}$ \\
\hline Experiment & 58,12 & 77,81 & 19,69 & 387,69 \\
\hline Control & 56,93 & 58,42 & 1,49 & 2,22 \\
\hline
\end{tabular}

Table above showed that score alteration of students' critical listening ability from pre-test to post-test both in experiment and control groups. Gain value (d) at experiment group (PMAIMI Model) was 19,69 bigger than gain (d) gotten from control group $(1,49)$. It could be seen that gain value of student' critical listening ability enhancement at experiment group was higher than control group (PMAIMA Model). Raising of critical listening ability at extended test in experiment class was 33,88\%, whereas control class was only 2,62\%. It showed that PMAIMI Model (interactive multimedia) proved be able to improve students' critical listening ability and was better than PMAIMA Model (audio media). It meant that interactive multimedia was more effective than audio media in improving students' critical listening ability.

\section{DisCUSSION AND CONCLUSION}

Students' critical listening ability after using interactive multimedia was effective and gave meaningful improvement. It coud be seen from the gain mark of the increasing students' critical listening ability in experiment group was higher than control group (PMAIMA Model) both in limited and extentensive tests. Gain value (d) limited test at experiment group (PMAIMI Model) was 24,36 was higher than gotten by control group at 3,99. From gain value it could be seen the improvement of students' critical listening ability at experiment group is higher than control group (PMAIMA Model). Gain Value (d) limited test at experiment group (PMAIMI Model) was 19,69 higher than gain (d) 1,49 at control group. From gain value could be seen that the improvement of students' critical listening abiltity was higher than control group (PMAIMA Model). It had showed that PMAIMI Model could improve students's critical listening 
and was better than PMAIMA Model. It means that PAMIMI Model was more effective than PMAIMA Model in improving students' critical listening ability.

Interacive multimedia in learning critical listening made some possibilities such as (1) effective activities like the students create active, creative, and effective learning process individually in measuring and developing each stage of listening learning model. (2) Interactive multimedia was effective learning media to improve students' critical listening skill. It was based on interactive multimedia utilizing effectiveness in increasing critical listening ability in experiment class was $42,98 \%$, whereas control class was only up 33,88\%, while control class rose only $2,62 \%$. (3) Critical listening strategy performance in interactive multimedia could improve students' critical listening ability so that interactive multimedia was useful as reference for listening learning media implementation (4) learning media with interactive multimedia was better to improve students critical listening skill if it was compared to audio learning media since listening not only aural aspect but also visual aspect integrated in multimedia.

\section{REFERENCES}

[1] Anderson, P. (1972). Language Skill in Elementary Education. New York: Macmillan Publishing Co., Inc.

[2] Blanco, Harold. (2007). "A Case Study of Language Learning in a Multimedia Spanish Class Environment in an Upward Bound Program" A Dissertation Presented to the Faculty of the College of Education of Ohio University.

[3] Brown, H. Douglas. (2004). Language Assesment, Principles, and Classroom Practies. San Francisco: Longman.

[4] Chapple, L. \& A. Curtis. (2000). Content-based instruction in Hong Kong: student responses to film. System, 28, 419-423.

[5] Costa, W. (1985). Developing Mind: A Resource Book for Teaching Thinking. Alexandria:ASCD.

[6] Embi, M.A. \& Latiff, A. A. (2004). Trainees' perception on E-Learn: A Malaysian based ESL Web Site, Internet Journal of eLanguage Learning \& Teaching, 1(2), 48-57.

[7] Field, J. (2009). Listening in the Language Classroom. Cambridge: Cambridge University Press.

[8] Flowerdew, J. \& Lindsay M. (2005). Second Langage Listening. Cambridge: Cambridge University Press.

[9] Fraenkel, Jack R. \& Norman E. Wallen. (2007). How to Design and Evaluate Research in Education (Seventh Edition). Boston: Mc Graw Hill.

[10] Greene, Harry A. et. al. (1969). Developing Language Skills in The Elementary Schools. Boston: Allyn and Bacon, Inc.

[11] Ginther, A. (2002). "Context and Content Visual and Peformance on Listening Comprehension Stimuli. Language Testing", 19 (2), 133-167.

[12] Harris, V. (2007). "Exploring Progression: Reading and Listening Strategy Instruction With Nearbeginner Learners of French". Language Learning Journal, 35(2), 189-204.

[13] Ivers, K. S., \& Barron, A. E. (2002). Multimedia Projects in Education. (Second Edition) Englewood, CO: Libraries Unlimited.

[14] Jones, Linda C. (2008). "Listening Comprehension Technology: Building the Bridge from Analog to Digital". CALICO Journal, 25(3), p-p 400-419.University of Arkansas.

[15] Logan, Lilian M. et.al. (1972).Creative Communication: Teaching the Languge Arts. Toronto: Mc Graw-Hill Ryerson Ltd.

[16] Mayer, R E., \& P. Chandler. (2001). When Learning is Just a Click Away: Does Simple Interaction Foster Deeper Understanding of Multimedia Messages. Journal of Educational Psychology, 93, 390-397.

[17] Meskill, C. (1996). "Listening Skills Development Through Multimedia". Jurnal of Educational Multimedia and Hypermedia. (1996) 5 (2), 179-201. Department of Educational Theory and Practice, University at Albany, State University of New York, Albany, USA.

[18] Morris, Anton C. et. al. (1969). College English. New York: Harcourt Boace \& Word, Inc.

[19] Ockey, G.J. (2007). "Constuct Implikations of Including Still Image or Video in Computer Based Listening Test". Language Testing, 24 (4), 517-537.

[20] Prabath, K. \& Andleigh. (1996). Multimedia System Design. New Jersey: Prentice Hall PTR.

[21] Siswosumarto, S. (1994). Proses dalam Mendesain Pesan dan Memvisualisasikan Ide. Jakarta: Depdikbud.

[22] Sudjana, N. \& A. Rivai. (2007). Media Pengajaran. Bandung: Sinar Baru Algesindo.

[23] Sutari, I. et. al. (1997). Menyimak. Jakarta: Depdikbud.

[24] Suyanto, M. (2005). Multimedia Alat untuk Meningkatkan Keunggulan Bersaing. Yogyakarta: Andi.

[25] Tarigan, D. (1986). Keterampilan Menyimak Modul 4-6. Jakarta: Karunika.

[26] Tarigan, H. G. (1990). Menyimak Sebagai suatu Keterampilan Berbahasa. Bandung: Angkasa.

[27] Thompson, K. et al. (2009). "Integrating Listening Model: An Approach to Teaching and Learning Listening". The Journal of General Education, 53, 3-4.

[28] Thompson, K. et. al. (2010). The Integrative Listening Model: An Approach to Teaching and Learning Listening (in the Listening and Human Comunication by Andrew D. Wolvin). United Kingdom: Blackwell Publishing Ltd.

[29] Vandergrift, L. (1999). Facilitating Second Language Listening Comprehension: Acquiring Successful Strategies. ELT Journal, 53(3), 168-176.

[30] Van Duzer, Carol. (1997). "Improving ESL Learners' Listening Skills: At the Workplace and Beyond". http://www.cal.org/caela/esl_resources/digests/LISTENQA.html. Bandung, 4 Februari 2013.

[31] Yusup, P.M. (1990). Komunikasi Pendidikan dan Komunikasi Instruksional. Bandung: Remaja Rosdakarya. 


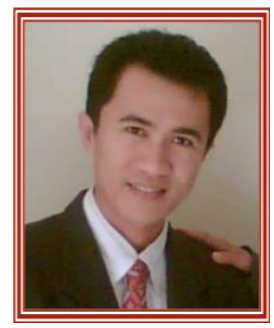

Arono was born in Bengkulu, 14 March 1977. He studied in Elementary School Padang Leban, 1989. Then, he continued his study to Junior High School 1 Seluma, 1992, and Senior High School 1 Seluma, 1995. After that, he took his bachelor degree in Padang State University by choosing Indonesian Language and Literature Education Department, 1990. He studied for his master in the same university, Padang State University, majoring Indonesia Language Education Department, 2004. He has been in Indonesia University of Education since 2010 for his doctoral degree majoring Indonesia Language Education Department.

He had been a Teacher in Senior High School in Bengkulu, Indonesia from 1999-2001. Then, he taught in Vocational High School in Padang, Indonesia from 2001-2004. After that, he has been teaching in Bengkulu University, Indonesia since 2005. He wrote many articles such as "Geography of Besemah Language Dialect, Discourse Analysis of Speech Act Dialog Liputan Enam SCTV, and Assessment Developing Learning Listening in Increasing Education of Language Character". He also did some researches in education field like "Development of Supplying, Placemat, and Establishment Models, Effort to Improve Students' writing Ability, and Innovation Implementation Guidance and Counseling Teachers and Lectures'. Now, he is doing a research about 'Development and Teaching a Language in Bengkulu University'.

Mr. Arono is one of the members of Linguistic Group, Academician Literature Association, and Teaching Language Club. He thanks so much to Prof. Dr. Maria Luisa Perez Canado, Mr. Feng Liu, and Journal of Language Teaching and Research that gave contribution to publish his article in this journal. 